\title{
Struktur Komunitas Jamur Tingkat Tinggi (Basidiomycetes: Polyporaceae) di Hutan Lindung Muka Kuning
}

\section{Structure Community Of High-level Fungi (Basidiomycetes : Polyporaceae) at Muka Kuning Protected Forest}

\author{
Putri Sinta, Lani Puspita*, Fauziah Syamsi \\ Program Studi Pendidikan Biologi Universitas Riau Kepulauan, *Corespondent email: \\ puspita.lani@gmail.com
}

Received: 27 February 2020 | Accepted: 27 June 2020 | Published: 20 July 2020

\begin{abstract}
Abstrak. Penelitian ini bertujuan untuk mengetahui struktur komunitas jamur tingkat tinggi (kelas Basidiomycetes: famili Polyporaceae) di Hutan Lindung Muka Kuning. Metode yang digunakan dalam penelitian ini adalah metode survei. Survei dilakukan dengan menelusuri wilayah stasiun pengamatan di Hutan Lindung Muka Kuning. Jenis penelitian ini adalah eksploratif dan data diolah secara ekologi kuantitatif. Berdasarkan hasil identifikasi, ditemukan 6 jenis jamur famili Polyporaceae, yaitu: Gloephyllum odoratum, Microporus xanthopus, Pycnoporus sanguineus, Trametes suaveolens, Trametes conchifer, dan Trametes versicolor. Substrat jamur yang ditemukan pada saat penelitian ini adalah batang kayu yang sudah mati. Berdasarkan analisis struktur komunitas, diperoleh Indeks Keanekaragaman Jenis yang tergolong sedang (nilai berkisar 1.05 - 1.63), Indeks Keseragaman Jenis yang tergolong tinggi (nilai berkisar 0.756 - 0.911), dan Indeks Dominansi yang tergolong rendah hingga sedang (nilai berkisar 0.223 - 0.452). Kerapatan jamur famili Polyporaceae berkisar antara 11 12 individu/ $\mathrm{m}^{2}$.

Kata kunci: Struktur Komunitas, Jamur Polyporaceae, Hutan Lindung Muka Kuning.

Abstract. This study aims to determine the community structure of high-level fungi (class Basidiomycetes: famili Polyporaceae) in Muka Kuning Protected Forest. The method used in this research is survey method. The survey was conducted by tracing the area of the observation station in the Muka Kuning Protected Forest. This is explorative research and data is analyzed using quantitative ecology method. Based on the results of the identification, found 6 types of Polyporaceae fungi, namely: Gloephyllum odoratum, Microporus xanthopus, Pycnoporus sanguineus, Trametes suaveolens, Trametes conchifer, and Trametes versicolor. The fungal habitats found were dead logs. Based on the community structure analysis, it was found that the Diversity Index is categorized medium (with values ranging from 1,05 - 1,63), the Evenness Index is categorized high (with values ranging from 0.756 0.911 ), and the Dominance Index is categorized low to medium (with a values ranging from 0.223 0.452). The density of the Polyporaceae is ranging between $11-13$ individuals $/ \mathrm{m}^{2}$.

Keywords: Community Structure, Polyporaceae Fungi, Muka Kuning Protected Forest.
\end{abstract}

\section{PENDAHULUAN}

Kota Batam mempunyai hutan yang cukup luas, yaitu sebesar 52,225.46 Ha, yang terdiri dari hutan yang dapat dikonversikan, hutan produksi, hutan suaka, dan hutan lindung. Keberadaan hutan-hutan ini menopang kehidupan flora dan fauna yang ada di Kota Batam. Salah satu hutan yang memiliki peranan cukup besar dan berada di tengah-tengah Kota Batam adalah Hutan Lindung Muka Kuning.

Keanekaragaman makhluk hidup atau keanekaragaman hayati memiliki arti yang penting untuk menjaga kestabilan ekosistem (Maisyarah, 2010). Hendarti (2008) dalam Septenggo (2016) menyatakan bahwa hutan merupakan suatu ekosistem yang terdiri dari berbagai komponen yang saling mempengaruhi dan ketergantungan, sehingga tidak dapat dipisahkan antara satu dengan yang lainnya. Komponen suatu ekosistem ada dua macam, yaitu komponen 
abiotik dan komponen biotik. Dari berbagai komponen tersebut, dekomposer merupakan komponen yang kurang mendapat perhatian, contohnya jamur. Jamur merupakan organisme yang tidak dapat menyediakan makanan sendiri dengan cara fotosintesis. Jamur mempunyai bentuk dan ukuran yang berbeda satu sama lain; jamur dikelompokkan menjadi jamur makroskopis dan mikroskopis.

Jamur Polyporaceae merupakan famili dari jamur Basidiomycetes. Jamur ini mempunyai ciri-ciri tubuh buah berbentuk setengah lingkaran dan banyak terdapat di kayu-kayu lapuk, contohnya adalah Ganoderma. Beberapa jamur dari famili Polyporaceae kelas Basidiomycetes bermanfaat sebagai obat (Tambaru et al., 2016).

Menurut Gandjar et al., (2006) dalam Annisa et al., (2017), diperkirakan sebanyak 69.000 jenis jamur (makro dan mikro) di seluruh dunia telah berhasil diidentifikasi; namun data mengenai jumlah jenis yang berhasil ditemukan di Indonesia belum diketahui; termasuk jamur dari famili Polyperaceae. Pada penelitian Yunida (2014) tentang inventarisasi jamur makroskopis di Gunung Senujuh Kabupaten Sambas, ditemukan 17 famili jamur; dalam penelitian tersebut didapatkan data bahwa spesies famili Polyporaceae memiliki jumlah spesies jamur terbanyak, yaitu 18 spesies. Pada penelitian Annisa et al., (2017) tentang keanekaragaman jenis jamur makroskopis di arboretum Sylva Universitas Tanjungpura, diperoleh data bahwa terdapat 9 spesies jamur yang termasuk ke dalam famili Polyporaceae. Pada penelitian Tambaru et al., (2016) tentang jenis-jenis jamur Basidiomycetes famili Polyporaceae di hutan pendidikan Universitas Hasanuddin di Bengo-Bengo Kecamatan Cenrana Kabupaten Maros diperoleh data bahwa terdapat 18 spesies jamur dari famili Polyporaceae di lokasi penelitian. Pada penelitian Nasution et al., (2018) tentang identifikasi jenis jamur makroskopis di Hutan Larangan Adat Rumbio Kabupaten Kambar Provinsi Riau, diperoleh data bahwa di lokasi penelitian ditemukan 12 spesies jamur dari famili Polyporaceae.

Penelitian tentang inventarisasi jenis-jenis jamur di Taman Wisata Alam (TWA) Muka Kuning pernah dilakukan oleh Harahap et al., (2017), namun penelitian tersebut belum membahas tentang struktur komunitas dari jamur famili Polyporaceae. Pada penelitian tersebut diperoleh data bahwa terdapat 15 spesies jamur kelas Basidiomycetes, dan 6 di antaranya termasuk ke dalam famili Polyporaceae. Karena belum ada data mengenai struktur komunitas jamur famili Polyporaceae, maka penelitian ini dilakukan dengan tujuan untuk mengetahui struktur komunitas jamur famili Polyporaceae di lokasi yang berdekatan, yaitu di Hutan Lindung Muka Kuning. Struktur komunitas yang dianalisis pada penelitian ini mencakup keanekaragaman jenis, keseragaman jenis, dominansi jenis, dan kerapatan jenis.

\section{METODE PENELITIAN}

Penelitian ini dilaksanakan pada bulan April 2018 di Hutan Lindung Muka Kuning. Hutan Lindung Muka Kuning terletak di Kawasan Simpang Dam, Muka Kuning, Kota Batam, Provinsi Kepulauan Riau, Indonesia. Alat yang digunakan dalam penelitian yaitu: meteran, tali, Global Positioning System (GPS), kompas, kamera, alat tulis, cutter atau gunting, penggaris, botol sampel, kertas label, kaca pembesar (LUP), $\mathrm{pH}$ meter tanah, dan thermometer tanah. Bahan yang digunakan dalam penelitian yaitu jamur sebagai objek penelitian dan alkohol $70 \%$ untuk mengawetkan koleksi jamur.

Jenis penelitian ini adalah eksploratif, dan data yang didapat diolah secara ekologi kuantitatif. Pengambilan sampel dilakukan di 3 stasiun pengamatan, yaitu bagian tepi hutan 
(Stasiun 1), bagian tengah hutan (Stasiun 2), dan bagian dalam hutan (Stasiun 3). Pada setiap stasiun ditetapkan 10 plot pengamatan berukuran $1 \mathrm{~m}$ x $1 \mathrm{~m}$ secara purposive (yaitu pada areaarea yang merupakan habitat jamur), sehingga dalam setiap stasiun pengamatan luas total area yang diamati adalah $10 \mathrm{~m}^{2}$. Di setiap plot pengamatan ditentukan titik koordinatnya menggunakan GPS. Adapun titik koordinat dari masing-masing plot pengamatan disajikan pada table dibawah ini.

Tabel 1. Titik koordinat plot pengamatan

\begin{tabular}{|c|c|c|c|c|c|}
\hline \multicolumn{2}{|r|}{ Stasiun 1} & \multicolumn{2}{|c|}{ Stasiun 2} & \multicolumn{2}{|c|}{ Stasiun 3} \\
\hline No. Plot & Titik Koordinat & No. Plot & Titik Koordinat & No. Plot & Titik Koordinat \\
\hline \multirow{2}{*}{1} & $001^{\circ} 04^{\prime} 12.16^{\prime \prime} \mathrm{N}$ & \multirow{2}{*}{11} & $001^{\circ} 04^{\prime} 19.99^{\prime \prime} \mathrm{N}$ & \multirow{2}{*}{21} & $001^{\circ} 04^{\prime} 24.32 ” \mathrm{~N}$ \\
\hline & $104^{\circ} 00^{\prime} 41.85^{\prime \prime} \mathrm{E}$ & & $104^{\circ} 00^{\prime} 22.05^{\prime \prime} \mathrm{E}$ & & $104^{\circ} 00^{\prime} 06.21^{\prime \prime} \mathrm{E}$ \\
\hline \multirow{2}{*}{2} & $001^{\circ} 04^{\prime} 12.14 " \mathrm{~N}$ & \multirow{2}{*}{12} & $001^{\circ} 04^{\prime} 20.02^{\prime \prime} \mathrm{N}$ & \multirow{2}{*}{22} & $001^{\circ} 04^{\prime} 24.28 ” \mathrm{~N}$ \\
\hline & $104^{\circ} 00^{\prime} 41.62^{\prime \prime} \mathrm{E}$ & & $104^{\circ} 00^{\prime} 21.92^{\prime \prime} \mathrm{E}$ & & $104^{\circ} 00^{\prime} 05.89^{\prime \prime} \mathrm{E}$ \\
\hline \multirow{2}{*}{3} & $001^{\circ} 04^{\prime} 12.06 " \mathrm{~N}$ & \multirow{2}{*}{13} & $001^{\circ} 04^{\prime} 20.24^{\prime \prime} \mathrm{N}$ & \multirow{2}{*}{23} & $001^{\circ} 04^{\prime} 23.75^{\prime \prime} \mathrm{N}$ \\
\hline & $104^{\circ} 00^{\prime} 41.44^{\prime \prime} \mathrm{E}$ & & $104^{\circ} 00^{\prime} 21.99 ” \mathrm{E}$ & & $104^{\circ} 00^{\prime} 05.87^{\prime \prime} \mathrm{E}$ \\
\hline \multirow{2}{*}{4} & $001^{\circ} 04^{\prime} 11.45^{\prime \prime} \mathrm{N}$ & \multirow{2}{*}{14} & $001^{\circ} 04^{\prime} 20.32^{\prime \prime} \mathrm{N}$ & \multirow{2}{*}{24} & $001^{\circ} 04^{\prime} 23.60^{\prime \prime} \mathrm{N}$ \\
\hline & $104^{\circ} 00^{\prime} 41.35^{\prime \prime} \mathrm{E}$ & & $104^{\circ} 00^{\prime} 21.76^{\prime \prime} \mathrm{E}$ & & $104^{\circ} 00^{\prime} 05.59^{\prime \prime} \mathrm{E}$ \\
\hline \multirow{2}{*}{5} & $001^{\circ} 04^{\prime} 11.45^{\prime \prime} \mathrm{N}$ & \multirow{2}{*}{15} & $001^{\circ} 04^{\prime} 20.22^{\prime \prime} \mathrm{N}$ & \multirow{2}{*}{25} & $001^{\circ} 04^{\prime} 23.92^{\prime \prime} \mathrm{N}$ \\
\hline & $104^{\circ} 00^{\prime} 41.41^{\prime \prime} \mathrm{E}$ & & $104^{\circ} 00^{\prime} 21.16^{\prime \prime} \mathrm{E}$ & & $104^{\circ} 00^{\prime} 05.13^{\prime \prime} \mathrm{E}$ \\
\hline \multirow{2}{*}{6} & $001^{\circ} 04^{\prime} 11.09 " \mathrm{~N}$ & \multirow{2}{*}{16} & $001^{\circ} 04^{\prime} 20.72^{\prime \prime} \mathrm{N}$ & \multirow{2}{*}{26} & $001^{\circ} 04 ' 25.01 \% \mathrm{~N}$ \\
\hline & $104^{\circ} 00^{\prime} 41.13^{\prime \prime} \mathrm{E}$ & & $104^{\circ} 00^{\prime} 20.64^{\prime \prime} \mathrm{E}$ & & $104^{\circ} 00^{\prime} 04.29^{\prime \prime} \mathrm{E}$ \\
\hline \multirow{2}{*}{7} & $001^{\circ} 04^{\prime} 11.75^{\prime \prime} \mathrm{N}$ & \multirow{2}{*}{17} & $001^{\circ} 04^{\prime} 20.74^{\prime \prime} \mathrm{N}$ & \multirow{2}{*}{27} & $001^{\circ} 04^{\prime} 24.66^{\prime \prime} \mathrm{N}$ \\
\hline & $104^{\circ} 00^{\prime} 39.68^{\prime \prime} \mathrm{E}$ & & $104^{\circ} 00^{\prime} 20.30^{\prime \prime} \mathrm{E}$ & & $104^{\circ} 00^{\prime} 04.04^{\prime \prime} \mathrm{E}$ \\
\hline \multirow{2}{*}{8} & $001^{\circ} 04^{\prime} 11.55^{\prime \prime} \mathrm{N}$ & \multirow{2}{*}{18} & $001^{\circ} 04^{\prime 2} 20.52^{\prime \prime} \mathrm{N}$ & \multirow{2}{*}{28} & $001^{\circ} 04^{\prime} 24.59^{\prime \prime} \mathrm{N}$ \\
\hline & $104^{\circ} 00^{\prime} 39.28^{\prime \prime} \mathrm{E}$ & & $104^{\circ} 00^{\prime} 20.03^{\prime \prime} \mathrm{E}$ & & $104^{\circ} 000^{\prime} 03.83$ " E \\
\hline \multirow{2}{*}{9} & $001^{\circ} 04 ' 11.48^{\prime \prime} \mathrm{N}$ & \multirow{2}{*}{19} & $001^{\circ} 04^{\prime} 20.70^{\prime \prime} \mathrm{N}$ & \multirow{2}{*}{29} & $001^{\circ} 04^{\prime} 25.08^{\prime \prime} \mathrm{N}$ \\
\hline & $104^{\circ} 00 ’ 39.30^{\prime \prime} \mathrm{E}$ & & $104^{\circ} 00^{\prime} 19.80^{\prime \prime} \mathrm{E}$ & & $104^{\circ} 00^{\prime} 03.35^{\prime \prime} \mathrm{E}$ \\
\hline \multirow{2}{*}{10} & $001^{\circ} 04 ' 11.77^{\prime \prime} \mathrm{N}$ & \multirow{2}{*}{20} & $001^{\circ} 04^{\prime} 20.72^{\prime \prime} \mathrm{N}$ & \multirow{2}{*}{30} & $001^{\circ} 04^{\prime} 25.33^{\prime \prime} \mathrm{N}$ \\
\hline & $104^{\circ} 00^{\prime} 38.41^{\prime \prime} \mathrm{E}$ & & $104^{\circ} 00^{\prime} 19.68^{\prime \prime} \mathrm{E}$ & & $104^{\circ} 00^{\prime} 02.98^{\prime \prime} \mathrm{E}$ \\
\hline
\end{tabular}

Data yang dikumpulkan dari setiap plot pengamatan adalah jenis substrat, suhu tanah, $\mathrm{pH}$ tanah, dan karakteristik morfologi jamur secara makroskopis. Karakteristik makroskopis morfologi jamur yang diamati meliputi: warna tubuh jamur, tekstur, bentuk cup, bentuk tepi cup, lebar cup, bentuk bilah, dan ada tidaknya tangkai. Berdasarkan karakteristik makroskopis morfologi jamur tersebut, kemudian jamur diidentifikasi untuk menentukan nama ilmiahnya. Dalam melakukan identifikasi, digunakan acuan buku identifikasi "Cendawan" (Widhiastuti dan Nurtjahja, 2013) dan jurnal-jurnal penelitian tentang jamur Polyporaceae.

\section{Analisis data}

\section{Indeks Keanekaragaman Jenis}

Setiap jumlah masing-masing spesies jamur Polyporaceae yang ditemukan dianalisis menggunakan indeks keanekaragaman (H') Shannon-Wienner (Odum, 1996). Rumusnya adalah sebagai berikut:

$$
H^{\prime}=-\sum\left(\frac{n i}{N} \cdot \ln \frac{n i}{N}\right)
$$

Keterangan: $H^{\prime}=$ Indeks Keanekaragaman Jenis Shannon-Wienner; ni = Jumlah jamur Polyporaceae jenis ke-i; $\mathrm{N}=$ Jumlah total jamur Polyporaceae. Kisaran nilai: $0 \leq \mathrm{H}^{\prime}<1=$ Tingkat 
keanekaragaman jenis rendah; $1 \leq \mathrm{H}^{\prime}<3$ =Tingkat keanekaragaman jenis sedang; $\mathrm{H}^{\prime} \geq$ 3=Tingkat keanekaragaman jenis tinggi

\section{Indeks Keseragaman Jenis}

Keseragaman jenis dihitung dengan menghitung indeks keseragaman jenis Evenness (E). Rumusnya adalah sebagai berikut (Odum, 1996):

$$
\mathrm{E}=\frac{\mathrm{H}^{\prime}}{\mathrm{H}^{\prime} \max }
$$

Keterangan: $\mathrm{E}=$ Indeks Keseragaman Evenness; $\mathrm{H}^{\prime}=$ Indeks keanekaragaman Shannon Wienner; H' $\max =\mathrm{Ln} \mathrm{S} ; \mathrm{S}=$ Jumlah jenisjamur Polyporaceae yang ditemukan. Kisaran nilai: 0 $\leq \mathrm{E}<0.3=$ Tingkat keseragaman jenis rendah; $0.3 \leq \mathrm{E}<0.6=$ Tingkat keseragaman jenis sedang $; 0.6 \leq \mathrm{E}<1.0=$ Tingkat keseragaman jenis tinggi.

\section{Indeks Dominansi Jenis}

Dominansi jenis dihitung dengan menghitung indeks Dominansi Simpson. Rumusnya adalah sebagai berikut (Odum, 1996):

$$
\mathrm{D}=\sum\left(\frac{\mathrm{ni}}{\mathrm{N}}\right)^{2}
$$

Keterangan: D = Indeks dominansi Simpson; ni = Jumlahjamur Polyporaceae jenis ke-i; $\mathrm{N}=$ Jumlah seluruh jenis jamur Polyporaceae; Kisaran nilai: $0 \leq \mathrm{D}<0.3=$ Tingkat dominansi jenis rendah; $0.3 \leq \mathrm{D}<0.6=$ Tingkat dominansi jenis sedang; $0.6 \leq \mathrm{D}<1.0=$ Tingkat dominansi jenis tinggi.

\section{Kerapatan}

Kerapatan dihitung untuk mengetahui jumlah individu jamur dalam luasa tertentu (Fahrul, 2008). Pada penelitian ini, kerapatan dihitung pada setiap station penelitian, dengan luas area pengamatan $10 \mathrm{~m}^{2}$ per stasiun. Kerapatan jamur Polyporaceae dihitung dengan rumus sebagai berikut:

$$
\mathrm{Pi}=\frac{\sum \text { individu tiap jenis (ind) }}{\text { luas pengamatan }\left(\mathrm{m}^{2}\right)}
$$

\section{HASIL DAN PEMBAHASAN}

Hutan Lindung Muka Kuning terletak di dekat permukiman dan Kawasan Industri Muka Kuning. Secara geografis hutan ini terletak antara $1^{\circ} 04^{\prime} 23.96$ N 10359’57.63 E. Secara administratif Hutan Lindung Muka Kuning termasuk dalam Kelurahan Sukajadi, Kecamatan Muka Kuning, Kota Batam, Provinsi Kepulauan Riau. Pada tahun 1992, hutan ini masih termasuk ke dalam kawasan Taman Wisata Alam Muka Kuning, namun berdasarkan rekomendasi analisis Tim Terpadu dalam lingkup Kepulauan Riau pada tahun 2015, radius 100 meter dari Taman Wisata Alam menjadi Hutan Lindung Muka Kuning. Hal ini ditetapkan berdasarkan Surat Keputusan (SK) Menteri Kehutanan Nomor: SK.76/MenLHK-II/2015.

Pada penelitian yang dilaksanakan selama bulan April 2018 ini ditemukan 6 jenis jamur dari famili Polyporaceae, yaitu Gloephylum odoratum, Microporus xanthopus, Pycnoporus sanguineus, Trametes suaveolens, Trametes conchifer, dan Trametes versicolor; data lebih rinci mengenai jamur Polyporaceae yang ditemukan disajikan pada Tabel 2. Merujuk data penelitian yang sebelumnya dilakukan oleh Harahap et al. (2017) pada bulan Maret - April 2017 di lokasi yang berdekatan (yaitu di TWA Muka Kuning), di TWA Muka Kuning juga ditemukan 6 jenis 
jamur dari famili Polyporaceae; namun jenis jamur yang ditemukan sedikit berbeda. Jenis jamur Polyporaceae yang ditemukan pada penelitian Harahap et al., (2017) adalah Fomes sp., Microporus xanthopus, Panus sp., Polyporus sp., Pycnoporus sanguineus, dan Tremetes sp. Pada penelitian yang dilaksanakan selama bulan April 2018 ini ditemukan 1 jenis jamur Polyporaceae yang tidak ditemukan di penelitian Harahap et al., (2017), yaitu jamur Gloephylum odoratum; namun ada 2 jenis jamur yang tidak ditemukan di penelitian selama bulan April 2018 ini, yaitu Fomes sp. dan Panus sp.

Tabel 2. Jenis-jenis jamur Polyporaceae yang teramati di kawasan Hutan Lindung Muka Kuning Kota Batam pada penelitian selama bulan April 2018

\begin{tabular}{lcccc}
\hline \multirow{2}{*}{ Nama Spesies } & \multicolumn{3}{c}{ Stasiun } & \multirow{2}{*}{ Jumlah Individu } \\
\cline { 2 - 4 } & Stasiun 1 & Stasiun 2 & Stasiun 3 & \\
\hline Gloephylum odoratum & 12 & 7 & 8 & 120 \\
Microporus xanthopus & 74 & 35 & 11 & 32 \\
Pycnoporus sanguineus & 13 & 3 & 16 & 76 \\
Trametes suaveolens & 17 & 30 & 29 & 84 \\
Trametes conchifer & - & 38 & 46 & 22 \\
Trametes versicolor & - & - & 22 & 361 \\
\hline Total individu/stasiun & 116 & 113 & 132 & \\
\hline Total Spesies/Stasiun & 4 & 5 & 6 & \\
\hline
\end{tabular}

Keterangan: (-) = Menyatakan tidak ada; Stasiun 1 = di hutan bagian tepi; Stasiun 2 = di hutan bagian tengah; Stasiun 3 = di hutan bagian dalam.

Tabel 2 di atas menyajikan data jumlah individu jamur Polyporaceae pada setiap stasiun pengamatan, yaitu Stasiun 1 (di hutan bagian tepi), Stasiun 2 (di hutan bagian tengah), dan Stasiun 3 (di hutan bagian dalam). Seluruh jamur tersebut ditemukan menempel pada substrat kayu yang sudah mati dan lapuk. Pada penelitian Harahap et al. (2017), seluruh jenis jamur Polyporaceae juga ditemukan pada substrat kayu lapuk; sedangkan jenis jamur lain ada yang ditemukan di substrat berbeda, yaitu Amauroderma rugosum (famili Ganodermataceae) dan Hygrocybe sp. (famili Hygrophoraceae) yang ditemukan di substrat tanah, serta Marasmius androsaceus (famili Tricholomataceae) yang ditemukan di serasah daun. Pada penelitian Nasution et al., (2018), juga didapatkan data bahwa sebagian besar jenis jamur famili Polyporaceae ditemukan di substrat kayu lapuk, sedangkan sebagian lagi ditemukan di susbtrat tanah, dan sebagian kecil di pohon hidup.

Telah disebutkan sebelumnya bahwa ditemukan 6 jenis jamur famili Polyporaceae di lokasi penelitian, jumlah jenis terbanyak (6 spesies) ditemukan di Stasiun 3, sedangkan di Stasiun 2 ditemukan 5 spesies dan di Stasiun 1 ditemukan 4 spesies. Jumlah jenis jamur famili Polyporaceae yang ditemukan di Hutan Lindung Muka Kuning ini umumnya tidak sebanyak yang ditemukan di lokasi lain. Pada penelitian Yunida et al. (2014) di Gunung Senujuh Kabupaten Sambas ditemukan 18 jenis jamur famili Polyporaceae, tiga diantaranya sama dengan jenis yang ditemukan pada penelitian ini, yaitu M. xanthopus, P. sanguineus, dan T.versicolor. Pada penelitian Nasution et al. (2018) di Hutan Larangan Adat Rumbio Kabupaten Kampar ditemukan 12 jenis jamur famili Polyporaceae, dan jenis-jenisnya pun berbeda dengan yang ditemukan di Hutan Lindung Muka Kuning ini. Pada penelitian Annisa et al., (2017) di Arboretum Sylva Universitas Tanjungpura, ditemukan 9 jenis jamur famili Polyporaceae; dua di 
antaranya sama dengan jenis yang ditemukan di penelitian ini, yaitu M. xanthopus dan T. versicolor. Namun jumlah jenis jamur famili Polyporaceae yang ditemukan pada penelitian di Hutan Lindung Muka Kuning ini masih lebih banyak dibandingkan yang ditemukan pada penelitian Marpaung (2017) di Taman Nasional (TN) Batang Gadis Kabupaten Mandailing Natal, yang mana pada penelitian di TN Batang Gadis tersebut ditemukan 5 jenis jamur famili Polyporaceae; satu diantaranya sama dengan yang ditemukan di penelitian ini, yaitu Pycnoporus sp.

Jumlah individu jamur Polyporaceae paling banyak ditemukan di Stasiun 3, yaitu 132 individu; sedangkan di Stasiun 1 ditemukan 116 individu dan di Stasiun 2 ditemukan 113 individu. Lebih banyaknya jumlah individu jamur yang ditemukan di Stasiun 3 diperkirakan karena pada bagian hutan ini kerapatan pohon lebih tinggi dibandingkan dua stasiun yang lainnya sehingga kondisinya lebih lembab, kondisi yang lembab ini cocok untuk pertumbuhan jamur; di Stasiun 3 ini juga lebih banyak dijumpai potongan kayu lapuk. Pada penelitian Nasution et al. (2018), yang mana menemukan 30 jenis jamur makroskopis di Hutan Larangan Adat Rumbio (12 diantaranya dari famili Polyporaceae), didapatkan data bahwa kelembaban tanah di lokasi penelitian tergolong tinggi, yaitu antara $75-89 \%$.

Spesies jamur yang ditemukan dengan jumlah paling banyak adalah M.xanthopus. Dalam penelitian ini $M$. xanthopus banyak dijumpai pada kayu dan ranting pohon yang sudah mati. Jamur yang paling sedikit ditemukan adalah $T$. versicolor, dalam penelitian ini, T.versicolor hanya dijumpai di Stasiun 3 (tepatnya pada batang pohon mati dan lapuk). Menurut Annisa et al., (2017), jamurjamur dari famili Polyporaceae umumnya bersifat saprofit, yaitu organisme yang mendapatkan nutrisi dari bahan organik yang sudah mati dan membusuk; sehingga lingkungan dengan banyak kayu dan ranting pohon yang sudah mati sangat cocok bagi pertumbuhan jamur Polyporaceae. Di lingkungan, jamur yang memiliki kemampuan tumbuhan relatif besar ini berperan sebagai dekomposer dan keberadaannya tidak merugikan organisme lain di sekitarnya. Uraian mengenai keenam jenis jamur famili Polyporaceae yang ditemukan pada penelitian disampaikan berikut ini:

\section{Gloephylum odoratum}

Jamur ini memiliki bentuk menyerupai bantalan, tidak memiliki tangkai (sessil), hidup soliter, dan habitatnya terdapat di kayu yang sudah mati. Bagian atas pileus berwarna putih kecoklatan dan bagian bawah berwarna putih. Jamur ini memiliki tekstur yang halus dan tidak memiliki lingkaran konsentris (Widhiastuti dan Nurtjahja, 2013).

\section{Microporus xanthopus}

Jamur ini mempunyai tubuh buah yang lebar, licin, dan teksturnya halus juga kaku. Bagian atas pileus berwarna putih atau krem kecoklatan dan bagian bawahnya berwarna putih. Lingkaran konsentris pada jamur sangat jelas, memiliki tangkai pendek, dan hidup berkoloni pada kayu mati (Widhiastuti dan Nurtjahja, 2013). Menurut Annisa et al., (2017), jamur jenis ini juga dimanfaatkan sebagai souvenir.

\section{Pycnoporus sanguines}

Jamur ini mempunyai tubuh buah berbentuk setengah lingkaran, bagian atas pileus berwarna orange kemerahan dan bagian bawah berwarna oranye, tubuh buah keras dengan tekstur seperti kulit, jamur ini tidak memiliki tangkai, dan permukaan bawahnya (lapisan 
himenium) berpori. Habitat jamur ini pada batang kayu yang sudah mati dan jamur ini tidak dapat dikonsumsi (Widhiastuti dan Nurtjahja, 2013).

\section{Trametes conchifer}

Jamur ini mempunyai tubuh buah berbentuk kipas atau ginjal, berwarna putih kecoklatan, dengan tekstur seperti kulit, tidak memiliki tangkai, permukaan atas bergaris-garis radial, dan terdapat lingkaran konsentris. Lapisan bagian bawah (himenium) berpori. Hidup soliter atau berkoloni pada kayu lapuk; jamur ini tidak dapat dikonsumsi karena teksturnya yang a lot (Widhiastuti dan Nurtjahja, 2013).

\section{Trametes versicolor}

Jamur ini mempunyai tubuh buah berwarna coklat kekuningan, berbentuk kipas atau ginjal, tubuh buah datar dan agak melengkung, struktur seperti kulit, tidak bertangkai, permukaan atasnya licin dan ada yang beludru, hidup berkoloni, dan lapisan himenium berpori. Habitat jamur ini adalah kayu lapuk (Widhiastuti dan Nurtjahja, 2013). Menurut Annisa et al., (2017), jamur jenis ini tidak dapat dimakan.

\section{Trametes suaveolens}

Jamur ini mempunyai tubuh buah berbentuk setengah lingkaran, tidak mempunyai tangkai, hidup berkoloni pada batang kayu yang sudah mati, permukaan atas tubuh buah licin dan berwarna putih krem kekuningan, permukaan bawah berwarna krem, dan lapisan himenium pada jamur berpori. Jamur ini hidup berkoloni (Widhiastuti dan Nurtjahja, 2013).

Berikut ini adalah hasil analisis struktur komunitas jamur famili Polyporaceae di lokasi penelitian, yang mencakup keanekaragaman jenis, keseragaman jenis, dominansi jenis, dan kerapatan jenis.

\section{Indeks Keanekaragaman}

Keanekaragaman jenis jamur Polyporaceae di lokasi penelitian ditentukan berdasarkan besar nilai Indeks Keanakeragaman Jenis Shannon-Wienner (H'). Dari hasil analisis diketahui bahwa nilai Indeks H' di lokasi penelitian berkisar antara 1.05 hingga 1.63. Nilai ini menunjukkan keanekaragaman jenis jamur famili Polyporaceae di lokasi penelitian tergolong sedang. Nilai Indeks H' paling tinggi ditemukan di Stasiun 3, dan paling rendah ditemukan di Stasiun 1. Kondisi lingkungan yang semakin lembab ke bagian dalam hutan dan semakin banyaknya ditemukan kayu yang lapuk diduga menjadi penyebab mengapa semakin ke dalam hutan keanekaragaman jenis jamur Polyporaceae semakin tinggi.

Pada penelitian Annisa et al., (2017), nilai Indeks H' untuk keseluruhan jenis jamur makroskopis di Arboretum Sylva Universitas Tanjungpura adalah 3.0385; namun jika dihitung hanya untuk jenis-jenis pada famili Polyporaceae, nilai Indeks H'-nya adalah 1.4772. Hal tersebut menunjukkan bahwa keanekaragaman jenis jamur famili Polyporaceae di Hutan Lindung Muka Kuning tidak jauh berbeda dengan yang ditemukan di Arboretum Sylva Universitas Tanjungpura. Pada penelitian Noverita et al., (2019) di Kawasan Suaka Margasatwa Bukit Rimbang Bukit Baling (SMBRBB) Provinsi Riau, didapatkan data bahwa Indeks H' jamur 
makro di lokasi tersebut berkisar antara 2.98 - 3.36, namun Indeks H' ini dihitung untuk keseluruhan famili jamur makro yang ada di lokasi tersebut.

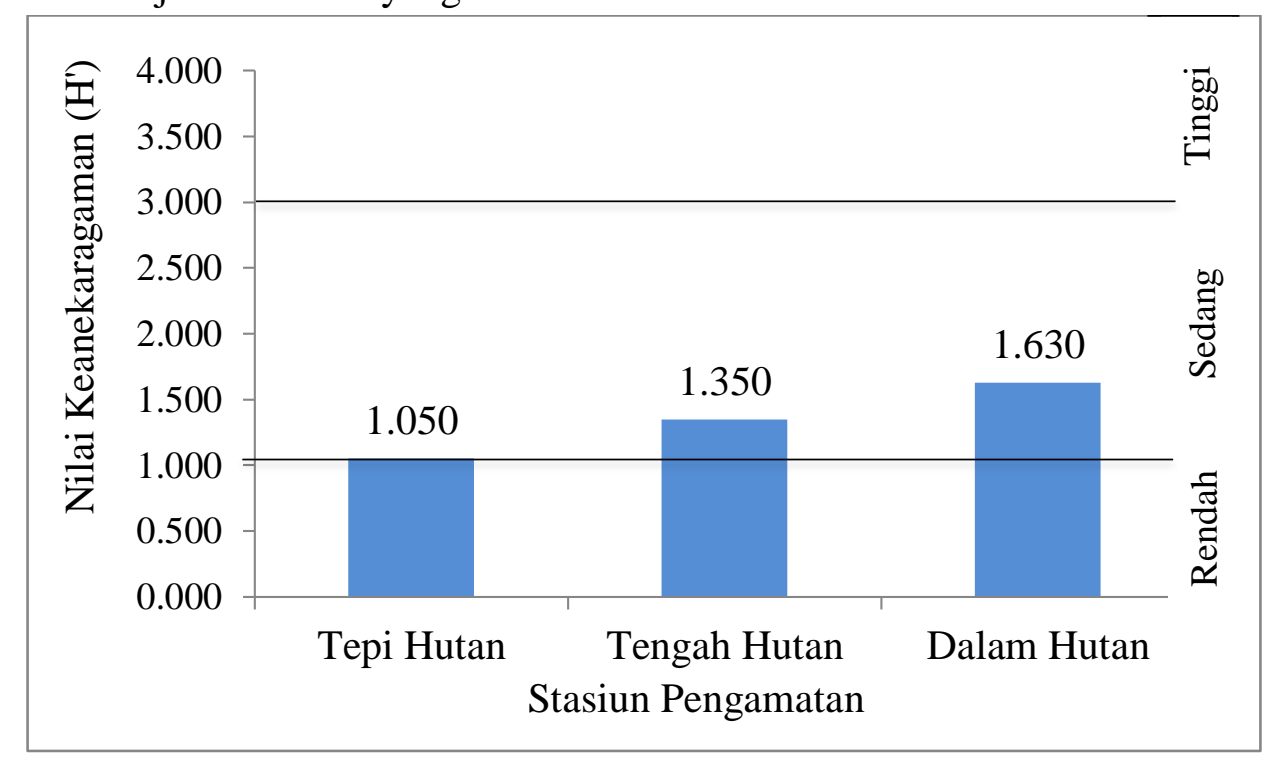

Gambar 1. Indeks Keanekaragaman Jenis Jamur Famili Polyporaceae

\section{Indeks Keseragaman Jenis}

Indeks Keseragaman Jenis Evenness (E) digunakan untuk menggambarkan komposisi individu tiap spesies yang terdapat dalam suatu komunitas (Odum, 1996). Nilai Indeks E di lokasi penelitian berkisar antara 0.756 - 0.911. Hal ini menunjukkan bahwa keseragaman jenis jamur Polyporaceae di ketiga stasiun tergolong tinggi. Nilai Indeks E paling tinggi ditemukan di Stasiun 3 yaitu 0.911, dan paling rendah di Stasiun 1, yaitu 0.756. Semakin ke dalam hutan, komposisi individu tiap spesies dalam komunitas jamur Polyporaceae semakin seragam.

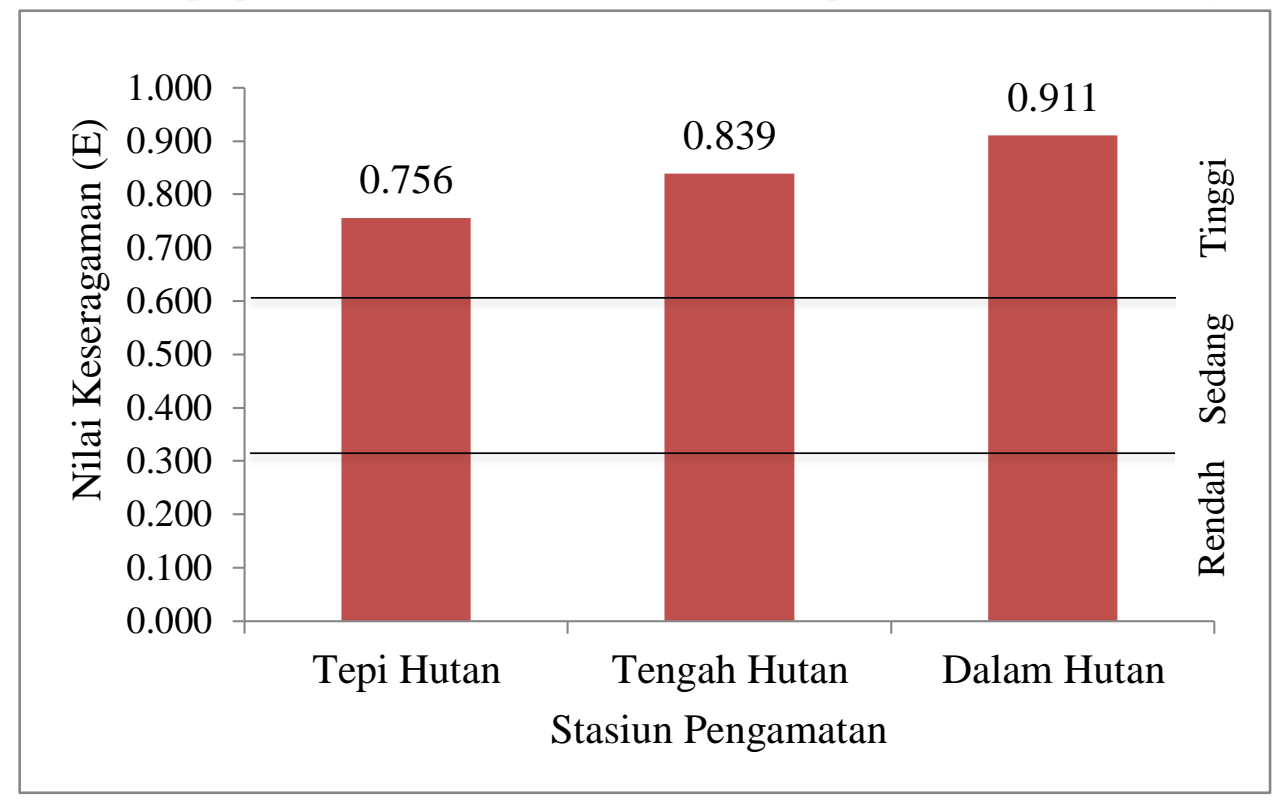

Gambar 2. Indeks Keseragaman Jenis Jamur Famili Polyporaceae

Pada penelitian Annisa et al., (2017), nilai Indeks E' untuk keseluruhan jenis jamur makroskopis di Arboretum Sylva Universitas Tanjungpura adalah 0.89337, dan jika dihitung hanya untuk jenis-jenis pada famili Polyporaceae, nilai Indeks E' adalah sebesar 0.672. Hal tersebut menunjukkan bahwa keseragaman jenis jamur famili Polyporaceae di Hutan Lindung 
Muka Kuning lebih tinggi dibandingkan dengan yang ditemukan di Arboretum Sylva Universitas Tanjungpura. Pada penelitian Noverita et al., (2019) di Kawasan Suaka Margasatwa Bukit Rimbang Bukit Baling (SMBRBB) Provinsi Riau, didapatkan data bahwa Indeks E' jamur makro di lokasi tersebut berkisar antara 0.806 - 0.858, namun Indeks H' ini dihitung untuk keseluruhan famili jamur makro yang ada di lokasi tersebut.

\section{Indeks Dominansi}

Untuk memperoleh informasi mengenai ada/tidaknya dominansi jamur dari famili Polyporaceae di Hutan Lindung Muka Kuning, maka dilakukan perhitungan nilai Indeks Dominansi. Ada beberapa faktor yang mempengaruhi ada/tidaknya spesies yang mendominasi, antara lain adalah faktor persaingan antar spesies yang ada. Hal tersebut berkaitan dengan iklim dan mineral yang diperlukan; jika iklim dan mineral yang dibutuhkan mendukung, maka spesies tersebut akan lebih unggul dan lebih banyak ditemukan (Syafei, 1990 dalam Maisyarah, 2010).

Hasil analisis menunjukkan bahwa Indeks Dominansi Jenis Simpson (D) di lokasi penelitian berkisar antara 0.233 - 0.452. Nilai Indeks D paling rendah ditemukan di Stasiun 3, selanjutnya di Stasiun 2. Nilai Indeks D di Stasiun 2 dan 3 ini tergolong dalam kategori dominansi jenis yang rendah, artinya pada kedua stasiun ini tidak ada jenis jamur Polyporaceae yang mendominasi. Hal tersebut sejalan dengan perhitungan nilai Indeks E di kedua stasiun tersebut yang cenderung mendekati 1 , artinya komposisi individu tiap spesies dalam komunitas jamur Polyporaceae tergolong seragam. Indeks D di Stasiun 1 (tepi hutan) tergolong sedang, yaitu 0.452. Ada 1 spesies yang cenderung mendominasi di Stasiun 1, yaitu Microporus xanthopus. Ada 74 individu jamur Microporus xanthopus di Stasiun 1, atau 64\% dari keseluruhan individu jamur famili Polyporaceae yang ada di stasiun tersebut.

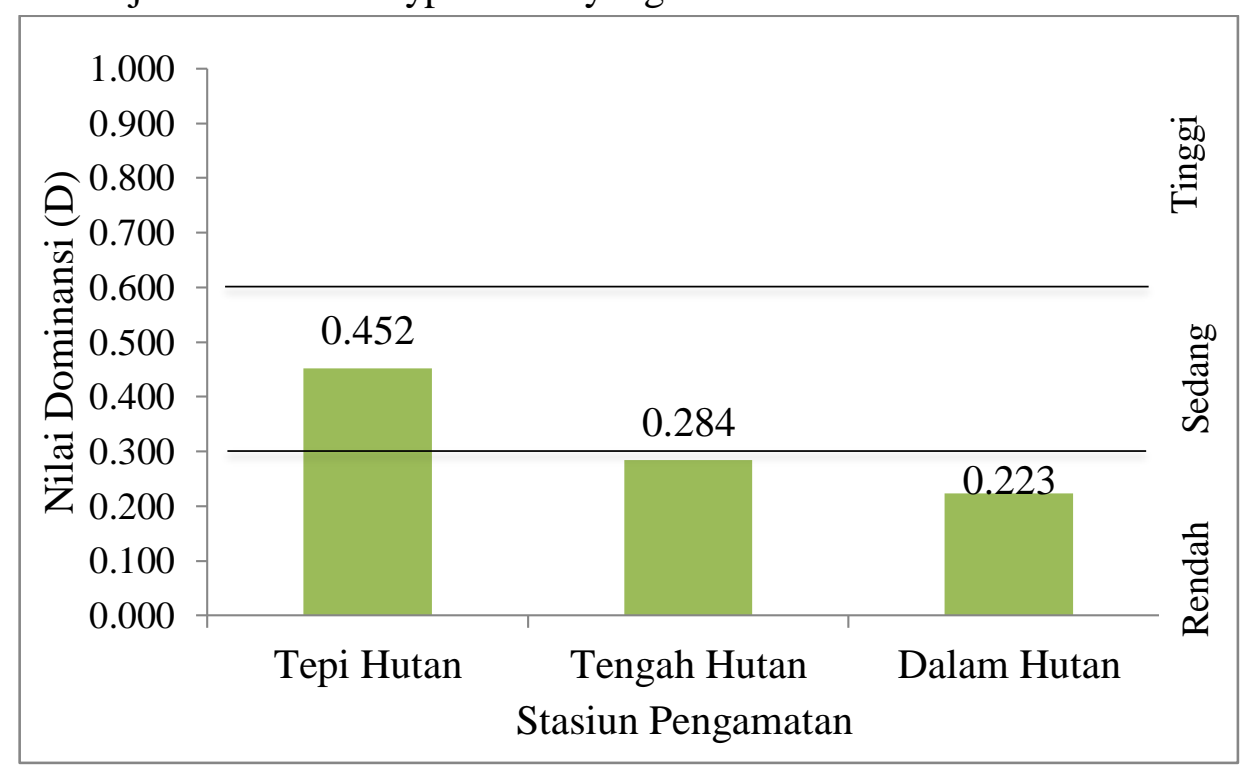

Gambar 3. Indeks Dominansi Jenis Jamur Famili Polyporaceae

Pada penelitian Annisa et al., (2017), nilai Indeks D untuk keseluruhan jenis jamur makroskopis di Arboretum Sylva Universitas Tanjungpura adalah 0.06174, dan jika dihitung hanya untuk jenis-jenis pada famili Polyporaceae, nilai Indeks D adalah 0.3180. Nilai tersebut berada pada kisaran nilai Indeks D yang ditemukan di stasiun pengamatan di Hutan Lindung Muka Kuning. 


\section{Kerapatan}

Kerapatan adalah jumlah individu per satuan luas pengamatan; dalam penelitian ini, total luas pengamatan di setiap stasiun pengamatan adalah $10 \mathrm{~m}^{2}$. Kerapatan jamur famili Polyporaceae pada masing-masing stasiun pengamatan dapat dilihat pada Tabel 3 di bawah ini. Tabel 3. Kerapatan jamur Famili Polyporaceae di Hutan Lindung Muka Kuning, Batam

\begin{tabular}{lc}
\hline Lokasi Pengamatan & Kerapatan Jamur (Individu/m² \\
\hline Stasiun 1 (Tepi Hutan) & 12 \\
Stasiun 2 (Tengah Hutan) & 11 \\
Stasiun 3 (Dalam Hutan) & 13 \\
\hline
\end{tabular}

Pada Tabel 3 di atas dapat dilihat bahwa kerapatan jamur Polyporaceae di ketiga stasiun pengamatan tidak jauh berbeda, yaitu berkisar antara 11-13 individu/m². Kerapatan jamur Polyporaceae paling tinggi ditemukan pada Stasiun 3. Tingginya kerapatan jamur Polyporaceae di stasiun tersebut diperkirakan karena di lokasi tersebut kerapatan pohon dan kelembaban lebih tinggi, dan lebih banyak dijumpai pohon lapuk dibandingkan di kedua stasiun lainnya, sehingga menjadi habitat yang cocok untuk kehidupan jamur seperti Polyporaceae ini. Hasil pengukuran suhu di Stasiun 3 menunjukkan angka berkisar antara $27-29^{\circ} \mathrm{C}$. Pada penelitian Nasution et al., (2018), suhu tanah di Hutan Larangan Adat Rumbio berkisar antara $23-31^{\circ} \mathrm{C}$, hal ini berarti kisaran suhu tanah di lokasi penelitian di Hutan Lindung Muka Kuning berada pada kisaran suhu tanah di lokasi penelitian jamur di Hutan Larangan Adat Rumbio. Hasil pengukuran $\mathrm{pH}$ tanah di Stasiun 3 menunjukkan angka berkisar antara 6.5-7. Nilai tersebut sedikit lebih tinggi dibandingkan dengan hasil penelitian Nasution et al., (2018) yang menyebutkan bahwa pH tanah di lokasi penelitiannya berkisar antara 5.5-6.4, dan hasil penelitian Annisa et al., (2018) melaporkan bahwa $\mathrm{pH}$ tanah berkisar antara 4.5 - 5.6.

\section{KESIMPULAN}

Ditemukan 6 spesies jamur dari famili Polyporaceae di Hutan Lindung Muka Kuning, yaitu G. odoratum, M. xanthopus, P. sanguineus, T. conchifer, T.suaveolens, dan T. versicolor. Spesies yang dijumpai dengan jumlah individu paling banyak adalah $M$. xanthopus, dan yang paling sedikit adalah T.versicolor. Indeks Keanekaragaman Jenis ( $\left.H^{\prime}\right)$ jamur famili Polyporaceae berkisar antara 1.05 - 1.63 (berada pada kategori sedang), Indeks Keseragaman Jenis (E) berkisar antara 0.756 - 0.911 (berada pada kategori tinggi), dan Indeks Dominansi Jenis (D) berkisar antara 0.223 - 0.452 (berada pada ketegori rendah hingga sedang). Kerapatan jamur famili Polyporaceae di lokasi penelitian berkisar antara 11-13 individu $/ \mathrm{m}^{2}$. Semakin menuju ke tengah hutan, keanekaragaman jenis, keseragaman jenis, dan kerapatan jamur famili Polyporaceae semakin tinggi, sedangkan dominansi jenisnya semakin rendah.

\section{REFERENSI}

Annisa, I., Ekamawati, H. A., dan Wahdina. 2017. Keanekaragaman Jenis Jamur Makroskopis di Arboretum Sylva Universitas Tanjungpura. Jurnal Hutan Lestari, 5 (4): 969-977.

Fachrul, F. M. 2008. Metode Sampling Bioekologi. Penerbit Bumi Aksara. Jakarta. 199 hal.

Harahap, L. C., Syamsi, F., dan Efendi, Y. 2017. Inventarisasi Jamur Tingkat Tinggi (Basidiomycetes) di Taman Wisata Alam Muka Kuning Batam. Simbiosa, 6 (2): 74-84.

Maisyarah, W. 2010. Struktur Komunitas Tumbuhan Penutup Tanah di Taman Hutan Raya R. Soerjo Cangar Malang. Jurnal Pembangunan dan ALam Lestari, 1 (1): 1-9. 
Marpaung, D. R. A. K. 2018. Keanekaragaman Jamur Basidiomycota di Kawasan Taman Nasional Batang Gadis (TNBG), Sopotinjak, Kecamatan Batang Natal, Kabupaten Mandailing Natal. EKSAKTA: Jurnal Penelitian dan Pembelajaran MIPA, 2 (2): 77-80.

Nasution, F., Prasetyaningsih, S. R., dan Ikhwan, M. 2018. Identifikasi Jenis dan Habitat Jamur Makroskopis di Hutan Larangan Adat Rumbio Kabupaten Kampar Provinsi Riau. Wahana Foresta: Jurnal Kehutanan, 13 (1): 64-76.

Noverita, Armanda, D. P., Matondang, I., Setia, T. M., dan Wati, R. 2019. Keanekaragaman dan Potensi Jamur Makro di Kawasan Suaka Margasatwa Bukit Rimbang Bukit Baling (SMBRBB) Provinsi Riau, Sumatera. Jurnal Pro Life, 6 (1): 26-43.

Odum, E. P. 1996. Dasar-Dasar Ekologi. Gajah Mada University Press.Yogyakarta. 697 hal.

Septenggo, D. 2016. Keanekaragaman Jenis Jamur Makroskopis Basidiomycota pada Hutan Penelitian dan Pendidikan Universitas Jambi di Hutan Harapan. [Skripsi]. Fakultas Keguruan dan Ilmu Pendidikan Universitas Jambi, Jambi.

Tambaru, E., Abdullah, A., dan Alam, N. 2016. Jenis-jenis Jamur Basidiomycetes Familia Polyporaceae di Hutan Pendidikan Universitas Hasanuddin Bengo-Bengo Kecamatan Cenrana Kabupaten Maros. BIOMA: Jurnal Biologi Makassar, 1 (1): 31-38.

Widhiastuti, R., dan Nurtjahja, K. 2013. Biodiversitas dan Identifikasi Cendawan di Taman Wisata Alam Sibolangit dan Sicikeh-cikeh Sumatera Utara. Self Publishing. Medan. 100 Hal.

Yunida, N. 2014. Inventarisasi Jamur di Gunung Senujuh Kabupaten Sambas dan Implementasinya dalam Pembuatan Flash Card. [Skripsi]. Fakultas Keguruan dan Ilmu Pendidikan Universitas Tanjungpura. Pontianak.

\footnotetext{
Authors:

Putri Sinta, Program Studi Pendidikan Biologi Universitas Riau Kepulauan, Jalan Pahlawan No. 99, Bukit Tempayan, Batu Aji, Kota Batam, Propinsi Kepulauan Riau, (29425), Indonesia, email: sintaputri687@gmail.com Lani Puspita, Program Studi Pendidikan Biologi Universitas Riau Kepulauan, Jalan Pahlawan No. 99, Bukit Tempayan, Batu Aji, Kota Batam, Propinsi Kepulauan Riau, (29425), Indonesia, email: puspita.lani@ gmail.com, Fauziah Syamsi, Program Studi Pendidikan Biologi Universitas Riau Kepulauan, Jalan Pahlawan No. 99, Bukit Tempayan, Batu Aji, Kota Batam, Propinsi Kepulauan Riau, (29425), Indonesia, email: fauziahsyamsi@gmail.com

This is an open-access article distributed under the terms of the Creative Commons Attribution License, which permits unrestricted use, distribution and reproduction in any medium, provided the original author and source are credited. (http://creativecommons.org/licenses/by/4.0/).
}

How to cite this article:

Sinta, P., Puspita, L., and Syamsi, F. 2020. Structure community of high-level fungi (Basidiomycetes: Polyporaceae) at Muka Kuning protected forest, Simbiosa, 9(1): 1-11. Doi. http://dx.doi.org/10.33373/sim-bio.v9i1.2294 